\title{
MONEY LAUNDERING RISK IN DEVELOPING AND TRANSITIVE ECONOMIES: ANALYSIS OF CYCLIC COMPONENT OF TIME SERIES
}

\author{
Valentyna LEVCHENKO ${ }^{\circledR}{ }^{1}$, Anton BOYKO ${ }^{2}{ }^{2}$, Victoria BOZHENKO ${ }^{3}$, \\ Serhii MYNENKO $\mathbb{D}^{4}$ \\ ${ }^{1}$ Department of Finance and Financial and Economic Security, \\ Kyiv National University of Technologies and Design, Kyiv, Ukraine \\ 2, 3, 4 Department of Economic Cybernetics, Sumy State University, Sumy, Ukraine

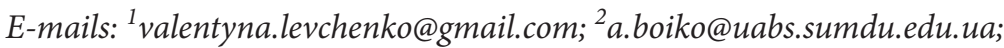 \\ ${ }^{3}$ v.roienko@uabs.sumdu.edu.ua (corresponding author); ${ }^{4}$ minensergey@gmail.com
}

Received 20 September 2019; accepted 27 October 2019

\begin{abstract}
Money laundering has become a global threat to the international stability and security, leading both to economic and social upheavals, and to an increase in terrorist threats. Therefore, an objective necessity arises for a more detailed study of the money laundering within the scope of its developmental patterns and time-dependent behaviour. The study mission is the development of a theoretical framework and methodological support for modelling the cyclic component of the money laundering risk. The correlation and regression are used for isolating the cyclic component. In turn, the Fourier harmonic analysis allows specifying the cyclic component. Additionally, we carried out a decomposition of time series, analysis of its volatility and persistence using the Hurst exponent. We determined the peaks, downturns and duration of the money laundering cycles in the developed economies and economies in transition, and established the possibility of predicting this process in the medium term. We proved the internationalization of the money laundering and the similarity of behaviour of trends that characterize it both for developed economies among themselves and between groups of countries. The further scientific research is needed within the framework of the imposition of trends in the development of the money laundering processes of some countries on others and the formation of international medium-term anti-fraud strategies.
\end{abstract}

Keywords: anti money laundering, money laundering risk, time series analysis, trend analysis, cyclic component, Fourier analysis, volatility, persistence.

JEL Classification: G32, C22, O17.

\section{Introduction}

The money laundering has assumed such proportions that it can serve as a source of financial and economic upheavals for any state and even individual regions of the world. The money laundering is inextricably linked with such processes in the country as corruption, capital outflow, use of tax havens by companies and banks to conceal the source of income and to evade taxes.

The development of Internet technologies, asymmetric information growth, and an increase in cybercrime aggravated the structure of crime and increased the money laundering risks. Thus, according to experts from PricewaterhouseCoopers (Global Annual Review 2019), global volumes of money laundering and terrorist financing operations are estimated at between $2 \%$ and 5\% of GDP of all countries or about US\$1-2 trillion per year. Only about $1 \%$ of the world's illegal financial flows were detected and confiscated by the controlling authorities (United Nations Office on Drugs and Crime, Research report 2011). The negative consequence of the money laundering is the loss of potential investment due to the shadowing of financial flows, the deterioration of the county's business reputation,

Copyright @ 2019 The Authors. Published by VGTU Press.

This is an Open Access article distributed under the terms of the Creative Commons Attribution License (http://creativecommons.org/licenses/by/4.0/), which permits unrestricted use, distribution, and reproduction in any medium, provided the original author and source are credited.. 
which means that it is no longer interesting to foreign investors.

In modern times, there is an urgent need for a comprehensive study of this negative phenomenon to protect society and the national economy from fraudulent operations, which are aimed at the money laundering.

Since any economic process has its own patterns and development trends, the hypothesis of the cyclic nature of the money laundering operations was put forward within the framework of the research. A more detailed study of this process will enable the development of effective anti-money laundering instruments and levers of state influence, as well as the formation of a set of preventive measures to minimize the money laundering risk.

\section{Literature review}

The issue of the anti-money laundering and terrorist financing has been widely discussed in the scientific literature. Thus, Reuter et al. (2004) investigate the origin of illegal income, as well as their laundering methods and markets. In addition, Sharman et al. (2009) paid considerable attention to the anti-money laundering system. Masciandaro (2017) focused on the study of international instruments for the concealment of illegal income, namely the use of tax havens in the process of money laundering in the context of globalization processes.

Another group of scientists studied the anti-money laundering issue. Thus, Araujo (2010) investigate ways to combat the money laundering through financial intermediaries that are actively involved in the process of legalization of incomes. Scientists offer an optimal strategy to maximize the benefits of each participant in this process, including financial intermediaries, based on an evolutionary game. Moreover, Nguyen (2018) suggest using preventive methods to combat the money laundering in the context of their interaction with financial confidentiality. Tjalling (2011) makes an attempt to predict illicit money laundering flows using traditional gravity models borrowed from international trade theory.

Arnone and Padoan (2008), Geiger and Wuensch (2010) propose the rigid state management of the money laundering processes. Thus, these authors analyze repressive antimoney laundering measures and the ability of countries to effectively use these measures. Dobrovic et al. (2018) research relationship between tax evasion and money laundering and find out the most viable instruments for combating this type of economic fraud.

A significant group of scientists applies various quantitative methods to assess various characteristics of the money laundering process. Thus, Grant et al. (2006), Savage et al. (2016) have developed a system for the real-time evaluation and detection of financial transactions that have signs of money laundering. Researchers such as J. Ferwerda, M. Kattenberg, Han-Hsin Chang, B. Unger, L. Groot, J. A. Bikker and M. Naheem (2018) are investigating the issue of money laundering in international trade using the gravity models and the regulatory approach. Moreover, Ferwerda and Kleemans (2019) undertook a study on developing a rating demonstrating the probability of using the sectors of the Netherlands economy for money laundering.

Melnikov et al. (2007), and Zhurbin (2011) are among the most prominent scholars of the post-Soviet area, who studies the anti-money laundering. This group of scientists pays special attention to the theoretical framework of the origin of this process, as well as the practical implementation of various methods for its implementation. From the point of view of the specifics of the use of bank services for money laundering, as well as the peculiarities of the use of mathematical tools for assessing indicators and the level of illegal use of financial institutions, it is necessary to pay attention to the works of such scholars as S. O. Dmytrov et al. (2014, 2015, 2017), Levchenko (2011) and Subeh (2017). Research of the harmful effect of money laundering on different economic and social aspects is a very important question that is revealed in numerous scientific papers. Thus, Lyeonov et al. (2018) research on how different internal and external imbalances, including money laundering, affect economic development of the country. Besides, Buriak et al. (2015) empirically identify how expansion of money laundering processes increase fragility of systemically important banks and financial system as a whole. Kordík and Kurilovská (2017) focused on the legal aspects of developing an effective system for counteracting the money laundering risks, and highlighted data sources for the evaluating this process. Sittlington and Harvey (2018) suggested an interesting experience in improving the anti-money laundering legislative framework. They studied the opinion of law enforcement; accountants; prosecutors; bankers, but also ex-offenders to form an effective institutional environment. This allowed identifying the main vulnerabilities of the legislative framework on anti-money laundering. Kulish et al. (2018) investigated the problem of overcoming the shadow economy in general and the money laundering, in particular, through the prism of institutional and structural factors These scientists offer the solution of this issue through the analysis of an influence on the structural policy and mechanism of its implementation, possible changes in the structure of the public administration, institutional changes, management of the state corporate rights, as well as a new stage of denationalization of the property and the privatization.

The rapid development of information technology has led to the emergence of cyber-attacks, which is one of the threats in the functioning of the anti-money laundering system. The study of this issue is reflected in the works 
of such scientists as Filipkowski (2008), Horne (2014), Mirea (2011), Piller and Zaccariotto (2009), Şcheau and Pop Zaharie (2017), Sekgwathe and Talib (2012). In turn, Stiawan et al. (2017) review various cyber-attack techniques and penetration test methodologies to assist security service personnel in relevant security assessments on their network systems. Simultaneously Federici (2007) notes that the use of various data mining methods in modern conditions can be useful for understanding the links between people and suspicious operations in order to track money laundering and terrorist financing activities.

Many scientists studied the use of electronic payment systems and online banking for money launderings, namely (More et al. 2015, Trautman 2016, Tropina 2014).

The use of cryptocurrency and other digital currencies as innovative financial instruments is another topical trend of money laundering through IT technologies. In particular, S. Mabunda (2018) justifies that the emergence and rapid spread of cryptocurrency in the world leads to the improvement of money laundering schemes through the Internet, since the peculiarities of circulation of virtual money allow for uncontrolled transactions within different countries. R. Stokes (2012) conducted a money laundering risk analysis of two virtual currencies: Linden Dollar, a global currency in the Second Life interactive online environment, and Bitcoin, an experimental virtual currency that allows transferring value using peer-to-peer technology. The study found that these virtual currencies are in demand among criminals in the field of money laundering, but they are not suitable for large-scale laundering. Šimonová et al. (2019) continued a study on the peculiarities of using innovative forms of money for money laundering. They focus on the existing problems in the field of regulation of the electronic money market and the mechanism for countering the illegal circulation of these assets for money laundering.

However, the latest technologies are used both for money laundering and for counteracting this process. Thus, Plaksiy et al. (2018) study the possibilities and benefits of applying Big Data for financial investigation data analysis. The visualization of ML/CFT typologies with the use of graphs is being considered as a result of the study. Leonov et al. (2019) engage in the active use of the latest information processing methods, succeeding in the prototyping of information system for monitoring banking transactions.

Despite a detailed study of cyber risks, and the money laundering, namely its nature, peculiarities of implementation and the mechanism of minimization, scientists have not sufficiently revealed the detailed aspects of its development. Thus, the cyclic nature of the money laundering was investigated only fragmentarily. At this stage of the economic science development, it is fair to say that Lilley (2006) made certain achievements in this aspect in "Dirty Dealing: The Untold Truth About Global Money
Laundering, International Crime and Terrorism". In this paper, P. Lilley points to the presence and indicates the reasons for the cyclic nature of the money laundering, but does not carry out a deep analysis of the cyclic component of the money laundering and does not distinguish it. At the same time, as noted above, the identification of the peaks and downturns in the money laundering intensity forms the basis for the development of effective tools for its timely prevention and further minimization.

Thus, the following procedure was proposed to structure scientific search in order to study the cycles of risk related to money laundering and terrorism financing:

- Stage 1. Collection and analysis of incoming information: Basel AML Index, which is selected as the main indicator of the study. The author's idea is that this index comprehensively characterizes the fact of money laundering.

- Stage 2. Selection of the trend and cyclical components of the Basel AML Index, to determine the existing patterns in the behavior of the studied process.

- Stage 3. Specification of the cyclic component. Based on the assumption that the AML process consists of the sum of oscillatory components, which peaks represent the greatest threat to money laundering, this stage involves the mathematical formalization of the identified tendency.

- Stage 4. Determination of the volatility and persistence of the process under study. The volatility indicator characterizes the magnitude of the Basel AML Index wave, and the persistence reflects the expected changes in the development of the phenomenon. These characteristics allow determining the level of finance security threat and predicting the risk of money laundering over time.

\section{Methodology and data}

\subsection{Data}

The Basel AML Index (The Basel Anti-Money Laundering Index) was proposed to be used to form the information base for the study. The methodological basis for the Basel AML Index was developed by the International centre for asset recovery. This index has 14 indicators, including:

- Indicators of the quality of the state system for counteracting the money laundering and terrorism financing, including data from the FATF Mutual Evaluation Reports, Tax Justice Network's Financial Secrecy Index and data from the International Narcotics Control Strategy State Department (INCSR) International Report. The share of this group of indicators in the index is $65 \%$.

- Transparency International Corruption Perceptions Index, which share is $10 \%$; 
- Financial transparency and standards indicators: the Corporate Transparency Index, the data of the WEF Global Competitiveness Report: the strength of the standards regulating the stock exchanges and the regulation of securities exchanges and the World Bank's Resource Allocation Index. These indicators have a share of $15 \%$ in the Basel AML Index;

- Indicators of public transparency and accountability (the share of 5\%);

- Indicators of political and legal risk (the share of 5\%).

Consequently, the analysis of the Basel AML Index provides an opportunity to assert a comprehensive description of the money laundering process through this complex indicator and, accordingly, the validity of its application in the study of the cyclic component.

Proceeding from the fact that developed economies and economies in transition have different stages of the financial system development, the efficiency of the activity of state regulation institutes, the level of justice of the judiciary, the total amount of money supply in the economy of the state, etc., it is proposed to conduct research within two groups of countries: developed economies and economies in transition. Confirmation of the hypothesis, regarding the differences in the cyclic processes of the money laundering for different groups of countries, will allow, in the future, forming a differentiated set of anti-fraud tools. Consequently, the input information is summarized in Table 1.

It is true to note that the Basel AML Index is essentially a disincentive, i.e., the greater its value, the more active the money laundering process is taking place in the country. Absolute values of this indicator (Table 1) indicate the lowest level of money laundering in the United Kingdom (developed economies) and the gradual reduction of the Basel AML Index by 2012-2018 in this country. At the same time, the Basel AML Index is the most significant for Tajikistan (economies in transition), so the indicator under study did not decrease below 8.1 units during the investigated period.

However, it should be noted that the lowest value of the Basel AML Index in 2018, which is characteristic of Azerbaijan (economies in transition), is lower than the corresponding value of this indicator in Switzerland (developed economies). This fact refutes the statement that the excess of the level of money laundering in economies in transition over the level of money laundering in the developed economies is obligatory. Consequently, the verification of another hypothesis regarding the different cyclic pattern trajectory of the Basel AML Index in the group of developed economies and the group of economies in transition becomes relevant.

\subsection{Methodology}

\subsubsection{Investigation of the cyclical component of the money laundering risk based on the Basel AML Index}

This task will be solved separately in the context of the developed economies and economies in transition. Consequently, the study of the cyclic component of the money laundering risk based on the Basel AML Index in the context of developed economies is proposed to be done in the following sequence:

- Decomposition of time series of the money laundering risk assessment by filtration of trend and cyclic components;

- Formalization of the trend component;

- Evaluation of the cyclic component;

- Visualization of the output time series, as well as its trend and cyclic components;

- Identification of characteristics such as peak, bottom, cycle duration (in case of its confirmation).

Thus, first, we will build graphs of the input time series of the Basel AML Index for each of the countries

Table 1. The dynamics of the Basel AML Index in the context of developed economies, economies in transition (source: Basel Institute on Governance)

\begin{tabular}{|c|c|c|c|c|c|c|c|c|}
\hline \multirow{2}{*}{$\begin{array}{l}\text { Type of } \\
\text { country }\end{array}$} & \multirow{2}{*}{ Country } & \multicolumn{7}{|c|}{ Year } \\
\hline & & 2012 & 2013 & 2014 & 2015 & 2016 & 2017 & 2018 \\
\hline \multirow{5}{*}{$\begin{array}{l}\text { Developed } \\
\text { economies }\end{array}$} & Germany & 5.80 & 5.79 & 5.49 & 5.48 & 5.33 & 4.78 & 4.44 \\
\hline & Italy & 5.49 & 5.54 & 5.37 & 5.23 & 5.36 & 5.41 & 5.09 \\
\hline & Switzerland & 5.78 & 5.76 & 5.54 & 5.51 & 5.46 & 5.15 & 5.33 \\
\hline & $\begin{array}{l}\text { United } \\
\text { Kingdom }\end{array}$ & 4.66 & 4.81 & 4.72 & 4.68 & 4.77 & 4.81 & 4.23 \\
\hline & United States & 5.26 & 5.24 & 5.20 & 5.18 & 5.17 & 4.85 & 5 \\
\hline \multirow{5}{*}{$\begin{array}{l}\text { Economies } \\
\text { in transition }\end{array}$} & Azerbaijan & 6.49 & 6.48 & 6.46 & 4.9 & 4.84 & 4.78 & 4.7 \\
\hline & Tajikistan & 8.12 & 8.27 & 8.34 & 8.26 & 8.19 & 8.28 & 8.3 \\
\hline & Russia & 5.66 & 5.75 & 6.29 & 6.26 & 6.22 & 6.22 & 5.83 \\
\hline & Ukraine & 6.62 & 6.47 & 6.55 & 6.56 & 6.57 & 6.52 & 6.06 \\
\hline & Kazakhstan & 5.12 & 5.94 & 5.94 & 5.93 & 5.88 & 6.42 & 6.36 \\
\hline
\end{tabular}




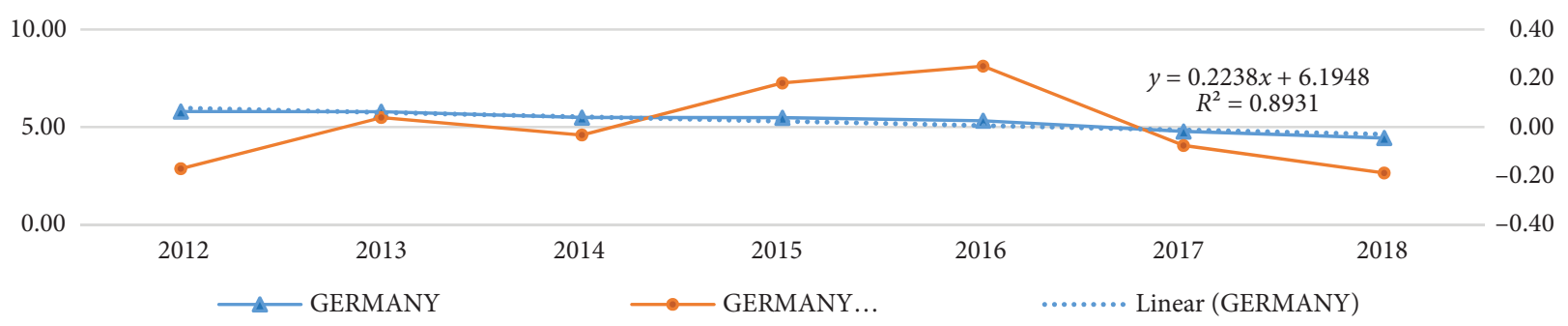

Figure 1. Visualization of input time series of the Basel AML Index, as well as its trend and cyclic components in the context of Germany over the period from 2012 to 2018 (source: authors' calculation)

under consideration (Germany, Italy, Switzerland, United Kingdom, and United States). It will allow using the MS Excel toolkit "Add Trend Line" to determine the trend component with the highest and economically feasible determination coefficient. As for the definition of the specification of the trend component of the Basel AML Index time series in Germany for the period from 2012 to 2018, we note the expediency of formalizing it using the linear function (Figure 1, Equation 1).

$$
A L M_{t}^{G}=-0.2238 \cdot t+6.1948
$$

where $A L M_{t}^{G}$ - the indicator of the money laundering risk assessment in the context of Germany for the $t$ year; $\mathrm{t}$ - year indicator $(t=1$ for 2012, $t=2$ for 2013, $t=3$ for 2014, $t=$ 4 for 2015, $t=5$ for 2016, $t=6$ for 2017, $t=7$ for 2018).

Similarly to Germany, we will make a specification of the trend component of the Basel AML Index time series in the context of Italy (linear function), Switzerland (linear function), United Kingdom (polynomial function) and United States (linear function) - Appendix A. After determining the trend component for the Basel AML Index for Germany, Italy, the United Kingdom, and the United States, we proceed to further research, namely: the evaluation of the cyclic component that is proposed to be carried out by subtracting the trend component from the input time series. The results of this step are presented in rows marked with "trend" in Table 2.

We will carry out similar calculations of the cyclic component of the money laundering risk based on the Basel AML Index, but in the terms of economies in transition: Azerbaijan, Tajikistan, Russia, Ukraine, and Kazakhstan.

Consequently, we will define the trend component, formalize its specification by constructing an equation with the highest determination coefficient. Thus, for Azerbaijan, it is expedient to formalize the trend component of the Basel AML Index time series using the linear function (Figure 2, Equation 2).

Table 2. The dynamics of the Basel AML Index, as well as its trend and cyclic component in tontext of developed economies (source: authors' calculation)

\begin{tabular}{|c|c|c|c|c|c|c|c|c|}
\hline \multirow{2}{*}{$\begin{array}{l}\text { Type of } \\
\text { country }\end{array}$} & \multirow{2}{*}{ Country } & \multicolumn{7}{|c|}{ Year } \\
\hline & & 2012 & 2013 & 2014 & 2015 & 2016 & 2017 & 2018 \\
\hline \multirow{15}{*}{$\begin{array}{l}\text { Developed } \\
\text { economies }\end{array}$} & Germany & 5.80 & 5.79 & 5.49 & 5.48 & 5.33 & 4.78 & 4.44 \\
\hline & Germany trend & 5.97 & 5.75 & 5.52 & 5.30 & 5.08 & 4.85 & 4.63 \\
\hline & Germany cyclic component & -0.17 & 0.04 & -0.03 & 0.18 & 0.25 & -0.08 & -0.19 \\
\hline & Italy & 5.49 & 5.54 & 5.37 & 5.23 & 5.36 & 5.41 & 5.09 \\
\hline & Italy trend & 5.51 & 5.46 & 5.41 & 5.36 & 5.30 & 5.25 & 5.20 \\
\hline & Italy cyclic component & -0.02 & 0.08 & -0.04 & -0.13 & 0.05 & 0.16 & -0.11 \\
\hline & Switzerland & 5.78 & 5.76 & 5.54 & 5.51 & 5.46 & 5.15 & 5.33 \\
\hline & Switzerland trend & 5.79 & 5.69 & 5.60 & 5.50 & 5.41 & 5.31 & 5.22 \\
\hline & Switzerland cyclic component & -0.01 & 0.07 & -0.06 & 0.01 & 0.05 & -0.17 & 0.11 \\
\hline & United Kingdom & 4.66 & 4.81 & 4.72 & 4.68 & 4.77 & 4.81 & 4.23 \\
\hline & United Kingdom trend & 4.64 & 4.76 & 4.81 & 4.80 & 4.72 & 4.58 & 4.37 \\
\hline & $\begin{array}{l}\text { United Kingdom cyclic } \\
\text { component }\end{array}$ & 0.02 & 0.05 & -0.09 & -0.12 & 0.05 & 0.23 & -0.14 \\
\hline & United States & 5.26 & 5.24 & 5.20 & 5.18 & 5.17 & 4.85 & 5 \\
\hline & United States trend & 5.30 & 5.24 & 5.18 & 5.13 & 5.07 & 5.01 & 4.96 \\
\hline & United States cyclic component & -0.04 & 0.00 & 0.02 & 0.05 & 0.10 & -0.17 & 0.04 \\
\hline
\end{tabular}




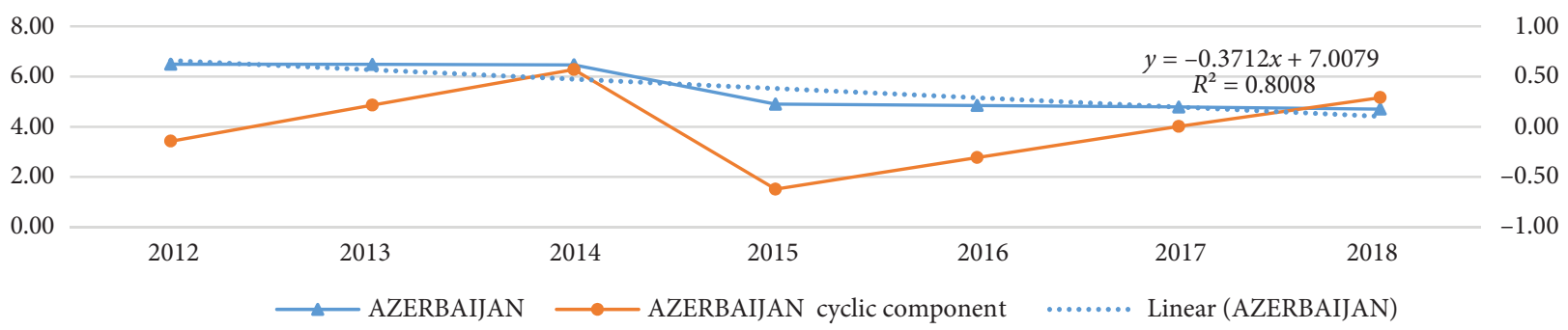

Figure 2. Visualization of the input time series of the BASEL AML INDEX, trend and cyclic components in the context of Azerbaijan for the period from 2012 to 2018 (source: authors' calculation)

$$
A L M_{t}^{A}=-0.3712 \cdot t+7.0079
$$

where $A L M_{t}^{A}$ - indicator of the money laundering risk assessment in the context of Azerbaijan for the $t$ year; $t$-year indicator $(t=1$ for 2012, $t=2$ for $2013, t=3$ for 2014, $t=4$ for 2015, $t=5$ for 2016, $t=6$ for 2017, $t=7$ for 2018).

In turn, the specification of the trend component of the Basel AML Index time series in the context of Tajikistan takes the form of power function, Russia - polynomial function, Ukraine - polynomial function, Kazakhstan linear function. Visualization of the results is presented in Appendix B. Having determined the trend component for each of the countries under consideration (Azerbaijan, Tajikistan, Russia, Ukraine, and Kazakhstan) within the Basel AML Index, we will evaluate the cyclic component, subtracting the trend component, respectively, from the input time series. The results of this step are presented in rows marked with "trend" in Table 3.

\subsubsection{Specification of the cyclic component of the time series using the harmonic Fourier analysis}

By providing a theoretical explanation for harmonic analysis, we note that this is a mathematical procedure for the description and analysis of periodic-recurring phenomena. Many complex problems are reduced to simpler, namely, the method of breaking up complex mathematical curves into the sum of relatively simple components (harmonics). There is no limitation on the number of calculated harmonics, but for the sake of simplification and reduction of their number, an appropriate degree of accuracy is chosen. It is accepted to allocate a number of harmonics, which will be sufficient to reflect the basic laws of the time series. Harmonic analysis neglects the nature of seasonal fluctuations, and takes into account the presence of a cyclic component in a dynamic series.

Thus, the cyclic component can be formalized using the harmonic analysis (by the Fourier transform method) for developed economies as follows:

Table 3. Dynamics of the Basel AML Index, as well as its trend and cyclic component in the context of economies in transition (source: authors' calculation)

\begin{tabular}{|c|c|c|c|c|c|c|c|c|}
\hline \multirow{2}{*}{ Type of country } & \multirow{2}{*}{ Country } & \multicolumn{7}{|c|}{ Year } \\
\hline & & 2012 & 2013 & 2014 & 2015 & 2016 & 2017 & 2018 \\
\hline \multirow{15}{*}{$\begin{array}{l}\text { Economies in } \\
\text { transition }\end{array}$} & Azerbaijan & 6.49 & 6.48 & 6.46 & 4.9 & 4.84 & 4.78 & 4.7 \\
\hline & Azerbaijan trend & 6.64 & 6.27 & 5.89 & 5.52 & 5.15 & 4.78 & 4.41 \\
\hline & Azerbaijan cyclic component & -0.14 & 0.22 & 0.57 & -0.62 & -0.31 & 0.00 & 0.29 \\
\hline & Tajikistan & 8.12 & 8.27 & 8.34 & 8.26 & 8.19 & 8.28 & 8.3 \\
\hline & Tajikistan trend & 8.18 & 8.22 & 8.25 & 8.26 & 28 & 8.29 & 8.30 \\
\hline & Tajikistan cyclic component & -0.06 & 0.05 & 0.10 & 0.00 & -0.09 & 0.00 & 0.00 \\
\hline & Russia & 5.66 & 5.75 & 6.29 & 6.26 & 6.22 & 6.22 & 5.83 \\
\hline & Russia trend & 5.58 & 5.93 & 6.17 & 6.28 & 6.27 & 6.13 & 5.87 \\
\hline & Russia cyclic component & 0.08 & -0.18 & 0.12 & -0.02 & -0.04 & 0.09 & -0.04 \\
\hline & Ukraine & 6.62 & 6.47 & 6.55 & 6.56 & 6.57 & 6.52 & 6.06 \\
\hline & Ukraine trend & 6.51 & 6.59 & 6.62 & 6.59 & 6.51 & 6.37 & 6.18 \\
\hline & Ukraine cyclic component & 0.10 & -0.12 & -0.06 & -0.03 & 0.07 & 0.15 & -0.12 \\
\hline & Kazakhstan & 5.12 & 5.94 & 5.94 & 5.93 & 5.88 & 6.42 & 6.36 \\
\hline & Kazakhstan trend & 5.45 & 5.61 & 5.78 & 5.94 & 6.11 & 6.27 & 6.44 \\
\hline & Kazakhstan cyclic component & -0.33 & 0.33 & 0.16 & -0.01 & -0.23 & 0.15 & -0.08 \\
\hline
\end{tabular}


- for Germany:

$$
\begin{aligned}
& t t_{j}:=-0.215 \cdot \cos \left[2 \pi \cdot j \frac{1}{4}+(1) \cdot 2.54\right]+ \\
& (-0.219) \cdot \cos \left[2 \pi \cdot j \frac{2}{8}+(-1) \cdot 3.142\right]
\end{aligned}
$$

- for Italy:

$$
\begin{aligned}
& t t_{j}:=0.244 \cdot \cos \left[2 \pi \cdot j \frac{1}{4}+(-1) \cdot 0.295\right]+ \\
& 0.145 \cdot \cos \left[2 \pi \cdot j \frac{2}{32}+(1) \cdot 0.911\right] ;
\end{aligned}
$$

- for Switzerland:

$$
\begin{aligned}
& t t_{j}:=0.096 \cdot \cos \left[2 \pi \cdot \frac{1}{4}+(1) \cdot 0.688\right]+ \\
& 0.1 \cdot \cos \left[2 \pi \cdot j \frac{2}{8}+(1) \cdot 1.582\right] ;
\end{aligned}
$$

- for the United Kingdom:

$$
\begin{aligned}
& t t_{j}:=-0.077 \cdot \cos \left[2 \pi \cdot \frac{1}{16}+(-1) \cdot 0.112\right]+ \\
& (-0.83) \cdot \cos \left[2 \pi \cdot j \frac{2}{8}+(1) \cdot 3.142\right]
\end{aligned}
$$

- for the United States:

$$
\begin{aligned}
& t t_{j}:=-0.061 \cdot \cos \left[2 \pi \cdot \frac{1}{8}+(-1) \cdot 2.987\right]+ \\
& (-0.076) \cdot \cos \left[2 \pi \cdot j \frac{2}{8}+(-1) \cdot 1.573\right] .
\end{aligned}
$$

The specification of the cyclic component of the Basel AML Index time series in the context of Azerbaijan, Tajikistan, Russia, Ukraine, and Kazakhstan for the period from 2012 to 2018 using the harmonic analysis (by the Fourier transform method) is as follows:

- for Azerbaijan:

$$
\begin{aligned}
& t t_{j}:=-0.396 \cdot \cos \left[2 \pi \cdot \frac{1}{4}+(-1) \cdot 0.611\right]+ \\
& (-0.411) \cdot \cos \left[2 \pi \cdot j \frac{2}{16}+(1) \cdot 2.325\right]
\end{aligned}
$$

- for Tajikistan:

$$
\begin{aligned}
& t t_{j}:=0.04 \cdot \cos \left[2 \pi \cdot \frac{1}{4}+(-1) \cdot 1.565\right]+ \\
& 0.044 \cdot \cos \left[2 \pi \cdot j \frac{2}{8}+(-1) \cdot 2.247\right]
\end{aligned}
$$

- for Russia:

$$
\begin{aligned}
& t t_{j}:=0.152 \cdot \cos \left[2 \pi \cdot \frac{1}{4}+(-1) \cdot 1.083\right]+ \\
& 0.095 \cdot \cos \left[2 \pi \cdot j \frac{2}{32}+(1) \cdot 0.397\right]
\end{aligned}
$$

- for Ukraine:

$$
\begin{aligned}
& t t_{j}:=0.091 \cdot \cos \left[2 \pi \cdot \frac{2}{8}+(1) \cdot 0.606\right]+ \\
& 0.086 \cdot \cos \left[2 \pi \cdot j \frac{3}{8}+(1) \cdot 1.654\right] ;
\end{aligned}
$$

- for Kazakhstan:

$$
\begin{aligned}
& t t_{j}:=0.225 \cdot \cos \left[2 \pi \cdot \frac{1}{4}+(-1) \cdot 2.194\right]+ \\
& 0.27 \cdot \cos \left[2 \pi \cdot j \frac{2}{4}+(1) \cdot 0.397\right] 1.886 .
\end{aligned}
$$

\subsubsection{Assessment of volatility and persistence of time series}

Absolute volatility is an indicator of the amplitude of fluctuations of the Basel AML Index, and it is formally measured by the ratio of the magnitude (the difference between the maximum and the minimum possible levels of the input time series) weighted by the mean square deviation:

$$
V_{t}^{a}=\frac{\max _{t} y_{t}-\min _{t} y_{t}}{S}
$$

where $V_{t}^{a}$-absolute volatility; $y_{t}$ - time series; $S$ - standard (mean square) deviation of the time series.

In turn, the relative volatility is defined as the ratio of the absolute volatility of the country under consideration to the maximum value of absolute volatility in the respective group of countries.

For the further determination of the stochasticity of the Basel AML Index time series (their persistence level), we use the Hurst exponent.

Thus, it is fair to note that there are three different classifications for different Hurst exponents:

- at $0<H<0.5$ - an anti-persistent time series, i.e. a series with a so-called return to the average: if the system develops for a certain period, then the system is expected to decline in the next period. The closer the $H$ value to zero, the more stable the system fluctuations.

$-H=0.5-$ corresponds to a stochastic time series.

$-0.5<H<1-$ persistent time series or trend-resistant series. Such a time series is characterized by the effect of "long memory". If the series began to grow, one should expect further growth. If the series began to decline, then this trend will continue in the future.

The following Hurst exponent was used to calculate the persistence:

$$
\frac{R}{S}=(\alpha \cdot N)^{H},
$$

where $H$ - the Hurst exponent; $N$ - a number of observation periods; $\alpha$ - a positive real number, given constant.

Thus,

$$
H=\frac{\log \left(\frac{R}{S}\right)}{\log (\alpha \cdot N)},
$$


where the scale of the accumulated deviation is as follows:

$$
\begin{gathered}
R=\frac{\max _{1 \leq u \leq N} Z_{u}-\min _{1 \leq u \leq N} Z_{u}}{\sigma_{u}} ; \\
Z_{u}=\sum_{1}^{u}\left(y_{i}-\bar{y}\right),
\end{gathered}
$$

where $\bar{y}$-the arithmetic mean of the time series; $\sigma_{u}$ - the mean squared accumulated deviation.

Consequently, when determining the persistence of the Basel AML Index time series, it is necessary, first, to calculate the deviation of the current time series from the arithmetic mean for the study period, the results of which are presented in Table 4.

Based on the deviation of the current time series from the mean arithmetic for the period under study presented in the previous table, we will define further intermediate calculations of the Hurst exponent, namely, we calculate the accumulated magnitude of the Basel AML Index time series, weighted by the accumulated mean square deviation (Table 5).

Using the data in Table 5, we will construct nonlinear regression equations of type (14), the graphical representation in the context of Germany is shown in Figure 3 and Equation (18).

$$
\frac{R}{S}=(\alpha \cdot N)^{H}=(0.9539 \cdot N)^{0.5387} .
$$

Equation (18) in the Basel AML Index time series in the context of Germany (cyclic component) demonstrates that the Hurst exponent is 0.5387 units.

Similarly, the calculation of the Hurst exponent of the Basel AML Index time series for other countries is described in Appendix C.

\begin{tabular}{|c|c|c|c|c|c|c|c|c|}
\hline \multirow{2}{*}{$\begin{array}{l}\text { Type of } \\
\text { country }\end{array}$} & \multirow{2}{*}{ Country } & \multicolumn{7}{|c|}{ Year } \\
\hline & & 2012 & 2013 & 2014 & 2015 & 2016 & 2017 & 2018 \\
\hline \multirow{10}{*}{$\begin{array}{l}\text { Developed } \\
\text { economies }\end{array}$} & Germany & 0.500 & 0.486 & 0.191 & 0.180 & 0.026 & -0.523 & -0.860 \\
\hline & $\begin{array}{l}\text { Germany cyclic } \\
\text { component }\end{array}$ & -0.171 & 0.039 & -0.033 & 0.180 & 249 & -0.076 & -0.188 \\
\hline & Italy & 0.138 & 0.181 & 0.016 & -0.126 & 0.001 & 0.056 & -0.266 \\
\hline & $\begin{array}{l}\text { Italy cyclic } \\
\text { component }\end{array}$ & -0.020 & 0.076 & -0.037 & -0.126 & 0.053 & 0.161 & -0.107 \\
\hline & Switzerland & 0.278 & 0.258 & 0.033 & 0.007 & -0.046 & -0.358 & -0.173 \\
\hline & $\begin{array}{l}\text { Switzerland cyclic } \\
\text { component }\end{array}$ & -0.008 & 0.068 & -0.062 & 0.007 & 0.050 & -0.167 & 0.113 \\
\hline & United Kingdom & -0.004 & 0.145 & 0.048 & 0.012 & 0.099 & 0.138 & -0.438 \\
\hline & $\begin{array}{l}\text { United Kingdom } \\
\text { cyclic component }\end{array}$ & 0.021 & 0.055 & -0.093 & -0.117 & 0.048 & 0.228 & -0.142 \\
\hline & United States & 0.132 & 0.109 & 0.072 & 0.054 & 0.039 & -0.280 & -0.126 \\
\hline & $\begin{array}{l}\text { United States cyclic } \\
\text { component }\end{array}$ & -0.038 & -0.004 & 0.016 & 0.054 & 0.096 & -0.167 & 0.043 \\
\hline \multirow{10}{*}{$\begin{array}{l}\text { Economies } \\
\text { in transition }\end{array}$} & Azerbaijan & 0.969 & 0.958 & 0.941 & -0.623 & -0.680 & -0.740 & -0.823 \\
\hline & $\begin{array}{l}\text { Azerbaijan cyclic } \\
\text { component }\end{array}$ & -0.145 & 0.215 & 0.569 & -0.623 & -0.309 & 0.002 & 0.290 \\
\hline & Tajikistan & -0.132 & 0.021 & 0.091 & 0.007 & -0.065 & 0.031 & 0.047 \\
\hline & $\begin{array}{l}\text { Tajikistan cyclic } \\
\text { component }\end{array}$ & -0.059 & 0.052 & 0.099 & -0.003 & -0.088 & -0.003 & 0.003 \\
\hline & Russia & -0.377 & -0.280 & 0.257 & 0.226 & 0.190 & 0.188 & -0.204 \\
\hline & $\begin{array}{l}\text { Russia cyclic } \\
\text { component }\end{array}$ & 0.078 & -0.182 & 0.122 & -0.019 & -0.043 & 0.089 & -0.045 \\
\hline & Ukraine & 0.136 & -0.007 & 0.071 & 0.080 & 0.094 & 0.045 & -0.420 \\
\hline & $\begin{array}{l}\text { Ukraine cyclic } \\
\text { component }\end{array}$ & 0.105 & -0.116 & -0.063 & -0.026 & 0.069 & 0.154 & -0.123 \\
\hline & Kazakhstan & -0.821 & -0.001 & -0.001 & -0.011 & -0.065 & 0.480 & 0.419 \\
\hline & $\begin{array}{l}\text { Kazakhstan cyclic } \\
\text { component }\end{array}$ & -0.326 & 0.329 & 0.164 & -0.011 & -0.230 & 0.150 & -0.076 \\
\hline
\end{tabular}

Table 4. Deviation of the current time series of the Basel AML Index from the arithmetic mean for the period under study (source: authors' calculation) 
Table 5. The accumulated magnitude of the Basel AML Index time series, weighted by the accumulated mean square deviation (source: authors' calculation)

\begin{tabular}{|c|c|c|c|c|c|c|c|}
\hline \multirow{2}{*}{$\begin{array}{l}\text { Type of } \\
\text { country }\end{array}$} & \multirow{2}{*}{ Country } & \multicolumn{6}{|c|}{ Periods } \\
\hline & & 2 & 3 & 4 & 5 & 6 & 7 \\
\hline \multirow{10}{*}{$\begin{array}{l}\text { Developed } \\
\text { economies }\end{array}$} & Germany & 1.414 & 1.771 & 1.800 & 2.278 & 2.722 & 2.659 \\
\hline & Germany cyclic component & 1.414 & 1.968 & 2.400 & 2.507 & 2.645 & 2.619 \\
\hline & Italy & 1.414 & 1.928 & 2.227 & 2.525 & 2.819 & 2.909 \\
\hline & Italy cyclic component & 1.414 & 1.853 & 2.440 & 2.520 & 2.863 & 2.785 \\
\hline & Switzerland & 1.414 & 1.800 & 1.885 & 2.147 & 2.735 & 2.819 \\
\hline & Switzerland cyclic component & 1.414 & 1.991 & 2.433 & 2.545 & 2.738 & 3.016 \\
\hline & United Kingdom & 1.414 & 1.969 & 2.226 & 2.404 & 2.333 & 2.891 \\
\hline & United Kingdom cyclic component & 1.414 & 1.906 & 2.033 & 2.100 & 2.782 & 2.863 \\
\hline & United States & 1.414 & 1.982 & 2.215 & 2.407 & 2.719 & 2.762 \\
\hline & United States cyclic component & 1.414 & 1.978 & 2.392 & 2.581 & 2.889 & 3.084 \\
\hline \multirow{10}{*}{$\begin{array}{l}\text { Economies } \\
\text { in } \\
\text { transition }\end{array}$} & Azerbaijan & 1.414 & 1.986 & 2.016 & 1.872 & 1.905 & 2.000 \\
\hline & Azerbaijan cyclic component & 1.414 & 2.000 & 2.339 & 2.575 & 2.874 & 2.982 \\
\hline & Tajikistan & 1.414 & 1.956 & 2.390 & 2.612 & 2.835 & 2.986 \\
\hline & Tajikistan cyclic component & 1.414 & 1.945 & 2.309 & 2.422 & 2.708 & 2.965 \\
\hline & Russia & 1.414 & 1.856 & 1.910 & 2.073 & 2.234 & 2.312 \\
\hline & Russia cyclic component & 1.414 & 1.851 & 2.258 & 2.572 & 2.687 & 2.891 \\
\hline & Ukraine & 1.414 & 1.997 & 2.429 & 2.743 & 2.965 & 2.920 \\
\hline & Ukraine cyclic component & 1.414 & 1.916 & 2.346 & 2.408 & 2.573 & 2.515 \\
\hline & Kazakhstan & 1.414 & 1.732 & 2.008 & 2.281 & 3.102 & 3.061 \\
\hline & Kazakhstan cyclic component & 1.414 & 1.923 & 2.338 & 2.419 & 2.605 & 2.824 \\
\hline
\end{tabular}

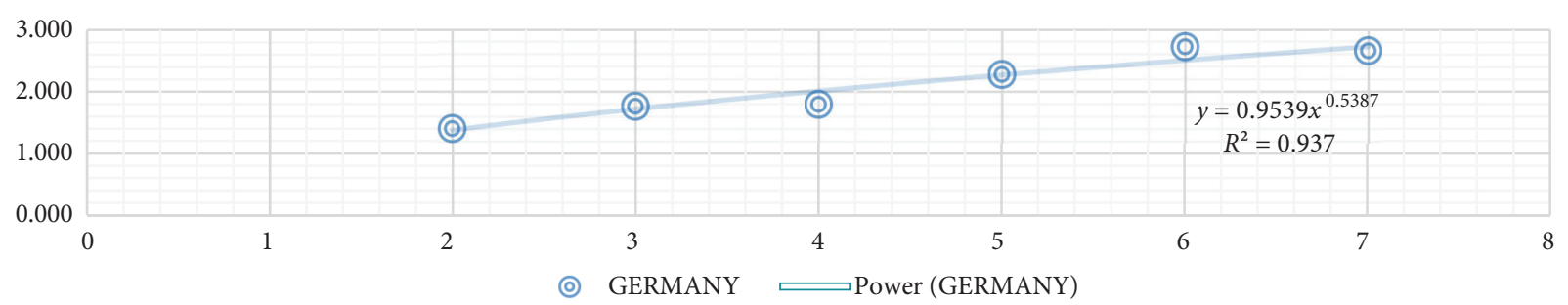

Figure 3. R/S analysis of the Basel AML Index time series in the context of Germany (cyclic component) (source: authors' calculation)

\section{Results}

Turning to the analysis of the results of the above-described stage of the study of the cyclic pattern of the money laundering process, we note that for developed economies, the peak, the bottom and duration of the studied process cycle are grouped in Table 6.

The data presented in Table 6 allows stating that for each of the developed economies there was a different number of peaks and downturns in the money laundering process, which, accordingly, led to a differentiated value of the duration of the cycle of this process. Analysing the same characteristics of the money laundering process in economies in transition (Table 7), we note that significant differences are not observed in developed economies. Thus, Tajikistan has the same cycle duration as Germany at the level of three
Table 6. Peak, bottom, cycle duration in the context of developed economies (source: authors' calculation)

\begin{tabular}{|c|c|c|c|c|}
\hline \multirow{2}{*}{$\begin{array}{l}\text { Type of } \\
\text { country }\end{array}$} & \multirow{2}{*}{ Country } & \multicolumn{3}{|c|}{$\begin{array}{c}\text { Characteristics of the money } \\
\text { laundering process }\end{array}$} \\
\hline & & Peak & Bottom & $\begin{array}{c}\text { Cycle } \\
\text { duration }\end{array}$ \\
\hline \multirow{5}{*}{$\begin{array}{l}\text { Developed } \\
\text { economies }\end{array}$} & Germany & $\begin{array}{l}2013 \\
2016\end{array}$ & 2014 & 3 years \\
\hline & Italy & $\begin{array}{l}2013 \\
2017\end{array}$ & 2015 & 4 years \\
\hline & Switzerland & $\begin{array}{l}2013, \\
2016, \\
2018\end{array}$ & $\begin{array}{l}2014 \\
2017\end{array}$ & 2.3 years \\
\hline & $\begin{array}{l}\text { United } \\
\text { Kingdom }\end{array}$ & $\begin{array}{l}2013 \\
2017\end{array}$ & 2015 & 4 years \\
\hline & United States & 2016 & 2017 & not found \\
\hline
\end{tabular}


years, and the significance of the cycle of the money laundering process for four years is typical both for Russia, for the United Kingdom, and for Italy.

Table 7. Peak, bottom, cycle duration in the context of economies in transition (source: authors' calculation)

\begin{tabular}{|c|c|c|c|c|}
\hline \multirow{2}{*}{$\begin{array}{l}\text { Type of } \\
\text { country }\end{array}$} & \multirow{2}{*}{ Country } & \multicolumn{3}{|c|}{$\begin{array}{c}\text { Characteristics of the money } \\
\text { laundering process }\end{array}$} \\
\hline & & Peak & Bottom & Cycle duration \\
\hline \multirow{5}{*}{$\begin{array}{l}\text { Eco- } \\
\text { nomies } \\
\text { in tran- } \\
\text { sition }\end{array}$} & Azerbaijan & 2014 & 2015 & Not found \\
\hline & Tajikistan & $\begin{array}{l}2014 \\
2017\end{array}$ & 2016 & 3 years \\
\hline & Russia & $\begin{array}{l}2014 \\
2017\end{array}$ & $\begin{array}{l}2013 \\
2016\end{array}$ & 4 years \\
\hline & Ukraine & $\begin{array}{l}2012 \\
2017\end{array}$ & $\begin{array}{l}2013 \\
2018\end{array}$ & 5 years \\
\hline & Kazakhstan & $\begin{array}{l}2013 \\
2017\end{array}$ & 2016 & 4 years \\
\hline
\end{tabular}

Continuing the study of the money laundering behavior, we note that summarizing the results of harmonic analysis (Table 8) in the context of developed economies, the following conclusions were drawn: Germany and Italy are most prone to cyclic fluctuations in the money laundering risk, as evidenced by the greatest values of fluctuations amplitude of 0.219 and 0.244 , respectively). In the context of the United States, the absence of a clearly identified cyclic component was previously determined, which is confirmed by the lowest value of the amplitude of the systematic component of the Basel AML Index time series for the given country at 0.061 . At the same time, the cyclical component in the context of Switzerland and the United Kingdom is present, but not as pronounced as in the case of Germany and Italy.

Table 8. Investigation of the cyclic component of the Basel AML Index time series (source: authors' calculation)

\begin{tabular}{|l|l|c|c|c|c|}
\hline \multirow{2}{*}{$\begin{array}{c}\text { Type of } \\
\text { country }\end{array}$} & Country & $\begin{array}{c}1^{\text {st }} \text { har- } \\
\text { monic } \\
\text { ampli- } \\
\text { tude }\end{array}$ & $\begin{array}{c}2^{\text {nd }} \text { har- } \\
\text { monic } \\
\text { ampli- } \\
\text { tude }\end{array}$ & $\begin{array}{c}1^{\text {st }} \text { har- } \\
\text { monic } \\
\text { phase }\end{array}$ & $\begin{array}{c}2^{\text {nd }} \text { har- } \\
\text { monic } \\
\text { phase }\end{array}$ \\
\hline \multirow{4}{*}{$\begin{array}{l}\text { Deve- } \\
\text { loped } \\
\text { eco- } \\
\text { nomies }\end{array}$} & Germany & 0.215 & 0.219 & -2.540 & 3.142 \\
\cline { 2 - 7 } & Italy & 0.244 & 0.145 & 0.295 & -0.911 \\
\cline { 2 - 7 } & $\begin{array}{l}\text { Unitzerland } \\
\text { Kingdom }\end{array}$ & 0.096 & 0.100 & -0.688 & -1.582 \\
\cline { 2 - 7 } & United States & 0.061 & 0.076 & -2.987 & -1.573 \\
\hline
\end{tabular}

Based on the results of the harmonic analysis (Table 9) in the context of economies in transition, it is fair to note that Russia and Kazakhstan are most prone to cyclic fluctuations in the money laundering risk, as evidenced by the highest values of the amplitude of fluctuations ( 0.152 and 0.270 , respectively). At the same time, in the context of Tajikistan and Ukraine, the cyclic component is present, but it is not so clearly expressed as in the case of Russia and Kazakhstan at the level of 0.044 and 0.091 .

Table 9. Investigation of the cyclic component of the Basel AML Index time series (source: authors' calculation)

\begin{tabular}{|l|l|l|l|l|l|}
\hline \multirow{2}{*}{$\begin{array}{c}\text { Type of } \\
\text { country }\end{array}$} & Country & $\begin{array}{c}1^{\text {st }} \text { har- } \\
\text { monic } \\
\text { ampli- } \\
\text { tude }\end{array}$ & $\begin{array}{c}2^{\text {nd }} \text { har- } \\
\text { monic } \\
\text { amplitude }\end{array}$ & $\begin{array}{c}1^{\text {st }} \text { har- } \\
\text { monic } \\
\text { phase }\end{array}$ & $\begin{array}{c}2^{\text {nd }} \\
\text { har- } \\
\text { monic } \\
\text { phase }\end{array}$ \\
\hline \multirow{4}{*}{$\begin{array}{l}\text { Econo- } \\
\text { mies in } \\
\text { tran- } \\
\text { sition }\end{array}$} & Azerbaijan & 0.396 & 0.411 & -0.611 & -2.325 \\
\cline { 2 - 7 } & Tajikistan & 0.040 & 0.044 & 1.565 & 2.247 \\
\cline { 2 - 7 } & Russia & 0.152 & 0.095 & 1.083 & -0.397 \\
\cline { 2 - 7 } & Kazakhstan & 0.091 & 0.086 & -0.606 & -1.654 \\
\hline
\end{tabular}

Turning to the analysis of the practical results of the Basel AML Index time series volatility (Table 10), we note the highest volatility of the quantitative assessment of the money laundering risk for Italy and the United Kingdom in the context of developed economies, as well as Tajikistan and Kazakhstan in the context of economies in transition. In addition, since the highest level of absolute volatility is observed in the case of Italy (developed economies) and Kazakhstan (economies in transition), the corresponding level of this indicator is set at 1.0. Thus, the Basel AML Index for Germany is $91.4 \%$, Italy, Switzerland - $96.6 \%$, the United Kingdom - 99.4\%, the United States - 95\%.

Table 10. Results of the Basel AML Index time series volatility assessment (source: authors' calculation)

\begin{tabular}{|l|l|c|c|}
\hline \multirow{1}{*}{$\begin{array}{c}\text { Type of } \\
\text { country }\end{array}$} & \multicolumn{1}{|c|}{ Country } & \multicolumn{2}{c|}{ Volatility } \\
\cline { 3 - 4 } & & absolute & relative \\
\hline \multirow{4}{*}{$\begin{array}{l}\text { Developed } \\
\text { economies }\end{array}$} & Germany & 2.659 & 0.914 \\
\cline { 2 - 4 } & Italy & 2.909 & 1.000 \\
\cline { 2 - 4 } & Switzerland & 2.819 & 0.969 \\
\cline { 2 - 4 } & United Kingdom & 2.891 & 0.994 \\
\cline { 2 - 4 } & United States & 2.762 & 0.950 \\
\hline \multirow{4}{*}{$\begin{array}{l}\text { Economies in } \\
\text { transition }\end{array}$} & Azerbaijan & 2.000 & 0.653 \\
\cline { 2 - 4 } & Tajikistan & 2.986 & 0.975 \\
\cline { 2 - 4 } & Russia & 2.312 & 0.755 \\
\cline { 2 - 4 } & Ukraine & 2.920 & 0.954 \\
\cline { 2 - 4 } & Kazakhstan & 3.061 & 1.000 \\
\hline
\end{tabular}

We systematize the results of the $\mathrm{R} / \mathrm{S}$ analysis of the Basel AML Index time series in the context of all the countries considered in Table 11.

Consequently, in the context of the 10 countries considered, stochastic time series were not found in either the actual data or the cyclic components. For those time series 
Table 11. Persistence of actual values and cyclic components of the Basel AML Index time series (source: authors' calculation)

\begin{tabular}{|c|c|c|c|c|c|}
\hline \multirow{2}{*}{ Type of country } & \multirow{2}{*}{ Country } & \multicolumn{4}{|c|}{ Persistence } \\
\hline & & \multicolumn{2}{|r|}{ actual values } & \multicolumn{2}{|r|}{ cyclic components } \\
\hline \multirow{2}{*}{$\begin{array}{l}\text { Developed } \\
\text { economies }\end{array}$} & Germany & 0.5387 & persistent time series & & \\
\hline & Germany cyclic component & & & 0.4975 & anti-persistent time series \\
\hline \multirow{8}{*}{$\begin{array}{l}\text { Developed } \\
\text { economies }\end{array}$} & Italy & 0.5798 & persistent time series & & \\
\hline & Italy cyclic component & & & 0.5727 & persistent time series \\
\hline & Switzerland & 0.5519 & persistent time series & & \\
\hline & Switzerland cyclic component & & & 0.5764 & persistent time series \\
\hline & United Kingdom & 0.4972 & anti-persistent time series & & \\
\hline & United Kingdom cyclic component & & & 0.5418 & persistent time series \\
\hline & United States & 0.526 & persistent time series & & \\
\hline & United States cyclic component & & & 0.6105 & persistent time series \\
\hline \multirow{10}{*}{$\begin{array}{l}\text { Economies in } \\
\text { transition }\end{array}$} & Azerbaijan & 0.2064 & anti-persistent time series & & \\
\hline & Azerbaijan cyclic component & & & 0.5895 & persistent time series \\
\hline & Tajikistan & 0.5938 & persistent time series & & \\
\hline & Tajikistan cyclic component & & & 0.5644 & persistent time series \\
\hline & Russia & 0.3707 & anti-persistent time series & & \\
\hline & Russia cyclic component & & & 0.5753 & persistent time series \\
\hline & Ukraine & 0.6003 & persistent time series & & \\
\hline & Ukraine cyclic component & & & 0.47 & anti-persistent time series \\
\hline & Kazakhstan & 0.6548 & persistent time series & & \\
\hline & Kazakhstan cyclic component & & & 0.5303 & persistent time series \\
\hline
\end{tabular}

where the Hurst exponent is less than 0.5 , it can be concluded that they are anti-persistent, i.e. the gradual return to the middle level of the series and a change in the trend (for the growing time series), and in the future perspective one should expect a decline and a reverse trend for the declining time series. This applies to countries such as the United Kingdom and Azerbaijan (the declining trend observed in 2012-2017 will be replaced by the growth trend), Russia - given the current increase in the money laundering, the reduction of this indicator should be expected in the long term. At the same time, countries such as Germany, Italy, Switzerland, the United States, Tajikistan, Ukraine, and Kazakhstan appeared to be trend-resistant in the context of the Basel AML Index. Turning to the analysis of the persistence of the cyclic components of the Basel AML Index time series, we observe the trend stability in the context of all the countries under consideration, except for Germany and Ukraine. It is also worth noting that stable fluctuations are characteristic of Azerbaijan and Russia since the Hurst exponent is close to zero.

\section{Findings for cybersecurity}

The increase in the number and scale of cyber threats in the information and communication system of the financial sector requires the development and implementation of effective preventive measures to counter cyber-attacks and cybercrime. The development of methodological foundations, which provide an opportunity to make effective management decisions and apply certain tools of influence in a well-defined period, is particularly relevant. One of such activities is the development of methodological support for the study of the cyclical nature of the money laundering process, which, in fact, serves as an informational basis for sound management decisions about the provision of cybersecurity on the part of various economic actors, namely:

- agencies engaged in state regulation, control and supervision - in identifying the risk of money laundering and developing measures to minimize or neutralize it through information systems; during the formation of the macroprudential policy of the state, in developing strategic plans for the development of the country, in ensuring the cybersecurity of state information resources, as well as in the determination of cyber threats and threats to national cybersecurity.

- financial and credit institutions as key intermediaries in money laundering - when conducting internal financial monitoring, in ensuring the protection of the information environment, in the formation of their strategic development vectors in the context of increasing money laundering risks using various 
information and innovation financial tools, as well as comprehensive cases of cyber-attacks.

Thus, an effective methodology has been developed and implemented to determine cyclical patterns in the study of money laundering processes that will allow potential users to determine their strategic development vectors, identify possible cyber risks that slow down their growth and choose effective tools to minimize this risk in the most optimal time span.

\section{Discussion}

The issue of analysing the money laundering process and further counteraction is relevant to any country worldwide: either for a developed economy or for an economy in transition. This is because about $50 \%$ of GDP may be in the shadow sector of the country's economy, and, first, it is necessary to eliminate the money laundering channels, which may be both residents and non-residents.

The method proposed in the article allows determining the cyclic fluctuations in the money laundering process at the country level. This may be used to predict the money laundering peaks and neutralize them in the future. The reliability of this task is confirmed by the definition that the money laundering processes are not stochastic, and therefore predictable.

Hypotheses concerning the dependence of the money laundering process on the type of economy (developed economies, economies in transition) have not been confirmed. At the same time, it is true to note that although the revealed characteristics of the development of the money laundering process are similar in developed economies and economies in transition, but these trajectories differ in their essence and in particular, causes. This is evidenced, for example, by the absence of the cycles of the Basel AML Index time series in the United States and Azerbaijan. Thus, in the first case, this is due to the functioning of an effective system of financial investigations and a stable level of the money laundering risk, and in the second case, on the contrary, the absence of both legislative barriers to the money laundering processes and the developed infrastructure of state control agencies, i.e. the development of this process in Azerbaijan is due to the demand of fraudsters.

The refutation of the hypothesis about the specific individual patterns of the money laundering process separately for developed economies and economies in transition is explained by the internationality of this process, i.e. the impossibility to limit its territory to one country. Typically, fraudsters in one country use financial institutions of several countries for money laundering, trying to hide the real sources of money.

Thus, the continuing development of cooperation between the state financial monitoring agencies of different countries within the anti-money laundering strategy is becoming relevant. This necessitates further research in the context of comparing cycles in different countries and the imposition of trends in the development of the money laundering processes of some countries to others, based on the volume of related financial transactions between economic agents of these countries. The obtained results will allow defining complex interstate anti-money laundering instruments and forming a unified strategy of activity of various state control agencies at a meso-level.

\section{Conclusions}

Understanding the cycles of money laundering and terrorist financing will allow predicting the maximum load and increase in the number of attacks on government agencies and financial institutions, which causes a direct threat to their cybersecurity. After identifying these cycles, it is possible to train the cyber police staff and test the cyber security system of financial institutions. Knowledge of the characteristics of these cycles in countries with different levels of economic development will allow responding flexibly to the challenges of cybersecurity on a global scale. These results will be useful both for the management of financial institutions for leveling the risk of loss of funds and information in cyber-attacks, and for the state, which is responsible for the stability of the financial system as a whole. Further research will focus on developing a scientific and methodological approach to assessing the most effective state and market instruments to counter the criminal proceeds legalization, depending on the trends in its cycle.

\section{Acknowledgements}

The publication contains the results of studies conducted under the grant from the President of Ukraine for the competitive project № 0119U103189 “Development of the prototype of the automated module for financial monitoring of the economic agents activities to counteract the criminal incomes legalization". The publication was prepared as part of the Research Project "Cybersecurity in the Fight Against Banking Fraud: Protecting Consumers of Financial Services and Increasing the Financial and Economic Security of Ukraine" (state registration № 0118U003574); Research Project "Improving the National System for Counteracting Money Laundering in the Context of Increasing Financial and Economic Security of the State" (state registration № 0117U002251).

\section{References}

Araujo RA (2010) An evolutionary game theory approach to combat money laundering. Journal of Money Laundering Control 13 (1): 70-78. https://doi.org/10.1108/13685201011010236 
Arnone M, Padoan P (2008) Anti-money laundering by international institutions: a preliminary assessment. European Journal of Law and Economics 26 (3): 361-386. https://doi.org/10.1007/s10657-008-9069-3

Buriak A, Lyeonov S, Vasylieva T (2015) Systematically important domestic banks: an indicator-based measurement approach for the Ukrainian banking system. Prague Economic Papers 24 (6): 715-728. https://doi.org/10.18267/j.pep.531

Dmytrov S, Medvid T (2017) An approach to the use of indicesbased analysis subject to money laundering and terrorist financing national risk assessment. SocioEconomic Challenges 1 (1): 35-47. https://doi.org/10.21272/sec.2017.1-04

Dmytrov SO, Levchenko LH, Medvid TA, Kuzmenko OV (2014) Determining the bank risk of using its services to legalize criminal income or financing terrorism during inspections. Sumy, Ukraine.

Dmytrov SO, Medvid TA, Kuzmenko OV (2015) National risk assessment of legalizing crime, financing terrorism and the proliferation of weapons of mass destruction: emerging challenges. Cherkasy, Ukraine.

Dobrovic J, Koraus A, Rajnoha R (2018) Activity management of the action plan for a sustainable fight against tax fraud and tax evasion in Slovakia as compared with the EU. Marketing and Management of Innovations 3: 313-323.

https://doi.org/10.21272/mmi.2018.3-28

United Nations Office on Drugs and Crime (2011) Estimating illicit financial flows resulting from drug trafficking and other transnational organized crimes research report https://www. unodc.org/documents/data-and-analysis/Studies/Illicit_financial_flows_2011_web.pdf

FATF (2019) FATF Recommendations http://www.fatf-gafi.org/

Federici FR (2007) Money laundering, terrorist financing and how to contrast them: data and text mining in business intelligence solutions. In: WIT Transactions on Information and Communication Technologies 38: 315-324.

https://doi.org/10.2495/DATA070311

Ferwerda J, Kleemans ER (2019) Estimating money laundering risks: an application to business sectors in the Netherlands. European Journal on Criminal Policy and Research 25 (1): 45-62. https://doi.org/10.1007/s10610-018-9391-4

Filipkowski W (2008) Cyber laundering: an analysis of typology and techniques. International Journal of Criminal Justice Sciences 3 (1): 15-27.

Geiger H, Wuensch O (2010) The fight against money laundering: An economic analysis of a cost-benefit paradoxon. Journal of Money Laundering Control 10 (1): 91-105. https://doi.org/10.1108/13685200710721881

Grant Jr, Reynolds T (2006 Method and system to evaluate antimoney laundering risk. United States Patent https://patentimages.storage.googleapis.com/ee/09/67/541789af380ebb/ US8412601.pdf

Horne R (2014) BBA Report The cyber threat to banking - A global industry challenge https://www.bba.org.uk/wp-content/ uploads/2014/06/BBAJ2110_Cyber_report_May_2014_WEB. pdf

International centre for asset recovery (2019) Methodological approach https://index.baselgovernance.org/methodology
Kordík M, Kurilovská L (2017) Protection of the national financial system from the money laundering and terrorism financing. Entrepreneurship and Sustainability 5 (2): 243-262. https://doi.org/10.9770/jesi.2017.5.2(7)

Kulish A, Petrushenko M, Reznik O, Kiselyova E (2018) The relations unshadowing in business activities: the economic and legal factors of security at the macroeconomic level. Problems and Perspectives in Management 16 (1): 428-436.

https://doi.org/10.21511/ppm.16(1).2018.40

Kuzmenko OV, Levchenko LH, Medvid TA (2011) Practical application of Bayesian analysis in financial monitoring at banks. Sumy, Ukraine.

Leonov S, Yarovenko H, Boiko A, Dotsenko T (2019) Information system for monitoring banking transactions related to money laundering. Proceedings of the Selected Papers of the 8th International Conference on Monitoring, Modeling \& Management of Emergent Economy (M3E2-EEMLPEED 2019), Odessa, Ukraine, May 22-24, 2019. https://doi.org/10.1051/shsconf/20196504013

Lilley P (2006) Dirty dealing. The untold truth about global money laundering, international crime and terrorism (3rd ed). UK and USA: Kogan Page.

Lyeonov SV, Vasylieva TA, Lyulyov OV, Kyrychenko KI (2018) Macroeconomic stability and its impact on the economic growth of the country. Montenegrin Journal of Economics 1: 159-170. https://doi.org/10.14254/1800-5845/2018.14-1.12

Mabunda S (2018) Cryptocurrency: the new face of cyber money laundering. Proceedings International Conference on Advances in Big Data, Computing and Data Communication Systems (IcABCD), Durban, South Africa, 17 Sep 2018. https://doi.org/10.1109/ICABCD.2018.8465467

Masciandaro D (2017) Global financial crime: terrorism, money laundering and offshore centres. Routledge. https://doi.org/10.4324/9781315254241

Melnikov VN, Movsesyan AG (2007) Anti-money laundering. Moscow, Russia.

Mirea V, Ionescu L, Blăjan A (2011) Fraud, corruption and cyber crime in a global digital network. Economics, Management and Financial Markets 6 (2): 373-380.

More MM, Jadhav, MP, Nalawade KM (2015) Online banking and cyber attacks: the current scenario. International Journal of Advanced Research in Computer Science and Software Engineering 5 (12): 743-749.

Naheem MA (2018) Is tackling Trade Based Money Laundering (TBML) through stricter reporting regulation the most effective response? Journal of Money Laundering Control 21 (3): 345-357. https://doi.org/10.1108/JMLC-08-2015-0034

Nguyen CL (2018) Preventing the use of financial institutions for money laundering and the implications for financial privacy. Journal of Money Laundering Control 21 (1): 47-58. https://doi.org/10.1108/JMLC-01-2017-0004

Piller G, Zaccariotto E (2009) Cyber-laundering: the union between new electronic payment systems and criminal organizations. Transition Studies Review 16 (1): 62-76. https://doi.org/10.1007/s11300-009-0048-3

Plaksiy K, Nikiforov A, Miloslavskaya N (2018) Applying big data technologies to detect cases of money laundering and counter financing of terrorism. In Proceedings - 2018 IEEE 
6th International Conference on Future Internet of Things and Cloud Workshops, W-FiCloud 2018 (pp. 70-77). Institute of Electrical and Electronics Engineers Inc. https://doi.org/10.1109/W-FiCloud.2018.00017

PwC (2019) Global annual review https://www.pwc.com/gx/en/ about/global-annual-review-2019.html\# 1

Reuter P, Edwin M Truman (2004) Chasing dirty money: the fight against money laundering. institute for international economics, Peterson institute press https://ideas.repec.org/b/iie/ppress/381.html

Savage D, Wang Q, Chou P, Zhang X, Yu X (2016) Detection of money laundering groups using supervised learning in networks https://arxiv.org/pdf/1608.00708.pdf

Şcheau MC, Pop Zaharie S (2017) Methods of laundering money resulted from cyber-crime. Economic Computation and Economic Cybernetics Studies and Research 51 (3): 299-314.

Sekgwathe V, Talib M (2012) Cyber forensics: computer security and incident response. International Journal on New Computer Architectures and Their Applications 2 (1): 127-137.

Sharman JC, Chaikin D (2009) Corruption and anti-moneylaundering systems: putting a luxury good to work. In Governance: An International Journal of Policy, Administration, and Institutions 22 (1): 27-45.

https://doi.org/10.1111/j.1468-0491.2008.01420.x

Sittlington S, Harvey J (2018) Prevention of money laundering and the role of asset recovery. Crime, Law and Social Change 70 (4): 421-441. https://doi.org/10.1007/s10611-018-9773-Z

Stiawan D, Idris MY, Abdullah AH, Aljaber F, Budiarto R (2017) Cyber-attack penetration test and vulnerability analysis. International Journal of Online Engineering 3 (1): 125-132. https://doi.org/10.3991/ijoe.v13i01.6407
Stokes R (2012) Virtual money laundering: the case of bitcoin and the Linden dollar. Information and Communications Technology Law 21 (1): 221-236. https://doi.org/10.1080/13600834.2012.744225

Subeh M, Boiko A (2017) Modeling efficiency of the state financial monitoring service in the context of counteraction to money laundering and terrorism financing. SocioEconomic Challenges 1 (2): 39-51.

https://doi.org/10.21272/sec.1(2).39-51.2017

Šimonová J, Čentéš J, Beleš A (2019) Financial analysis of innovative forms of money, Entrepreneurship and Sustainability 7 (1): 69-80. https://doi.org/10.9770/jesi.2019.7.1(6)

Tax justice network (2019) https://www.taxjustice.net/

The World Bank (2019) https://www.worldbank.org

The World Economic Forum (2019) https://www.weforum.org/

Tjalling C (2011) Gravity models of trade-based money laundering. Koopmans Research Institute. Utrecht School of Economics. Utrecht University https://www.uu.nl/files/rebousedp201111-16pdf

Transparency International (2019) https://www.transparency.org/

Trautman LJ (2016) E-commerce, cyber, and electronic payment system risks: lessons from PayPal. 16 U.C. Davis Business Law Journal 16 (1): 261-292 https://doi.org/10.2139/ssrn.2314119

Tropina T (2014) Fighting money laundering in the age of online banking, virtual currencies and internet gambling. ERA Forum 5 (1): 69-84. https://doi.org/10.1007/s12027-014-0335-2

Zhubrin RV (2011) The fight against money laundering: theoretical and practical aspects. Moscow, Russia. 


\section{APPENDIX A}

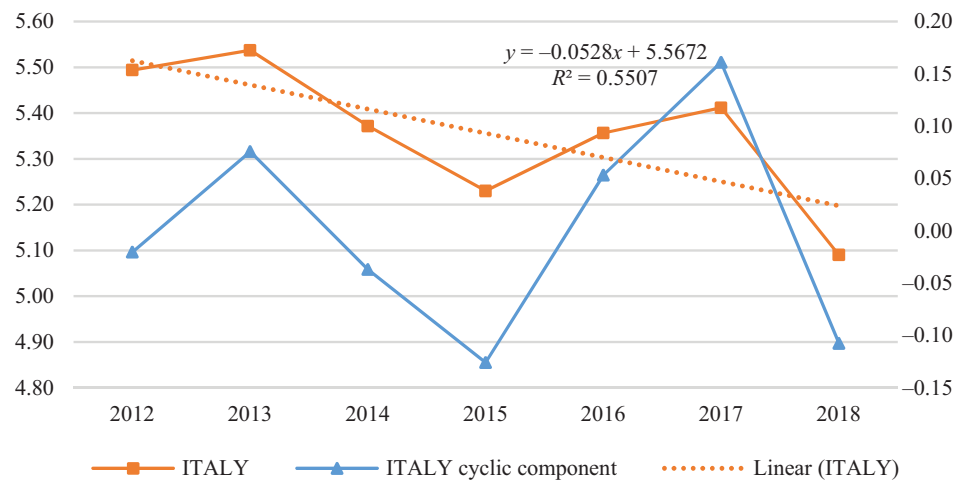

Figure A1.Visualization of the input time series of BASEL AML INDEX, trend and cyclic components in the context of Italy for the period from 2012 to 2018 (source: authors' calculation)

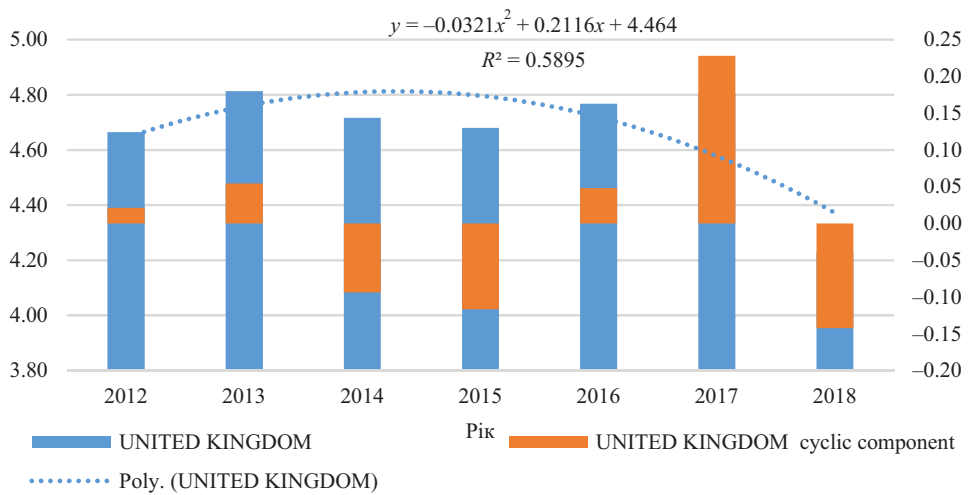

Figure A2. Visualization of the input time series of the BASEL AML INDEX, trend and cyclic components in the context of the United Kingdom for the period from 2012 to 2018 (source: authors' calculation)

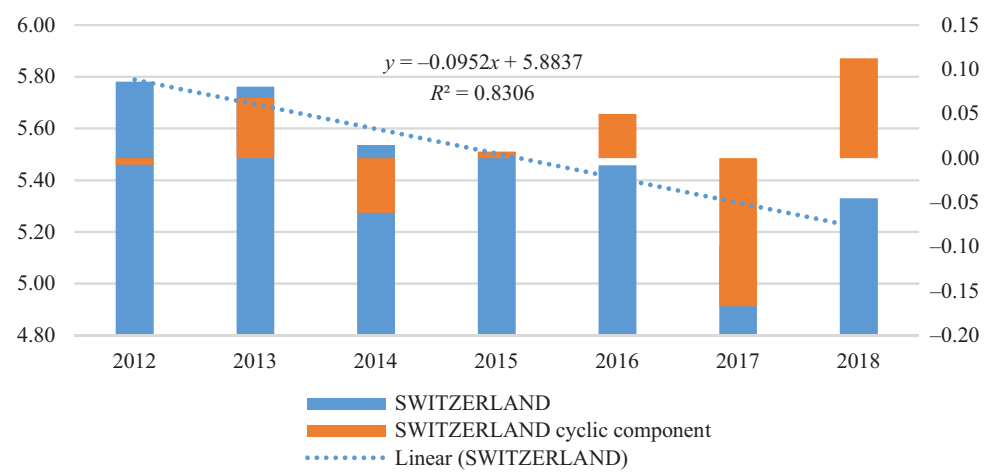

Figure A3. Visualization of the input time series of the BASEL AML INDEX, trend and cyclic components in the context of Switzerland for the period from 2012 to 2018 (source: authors' calculation)

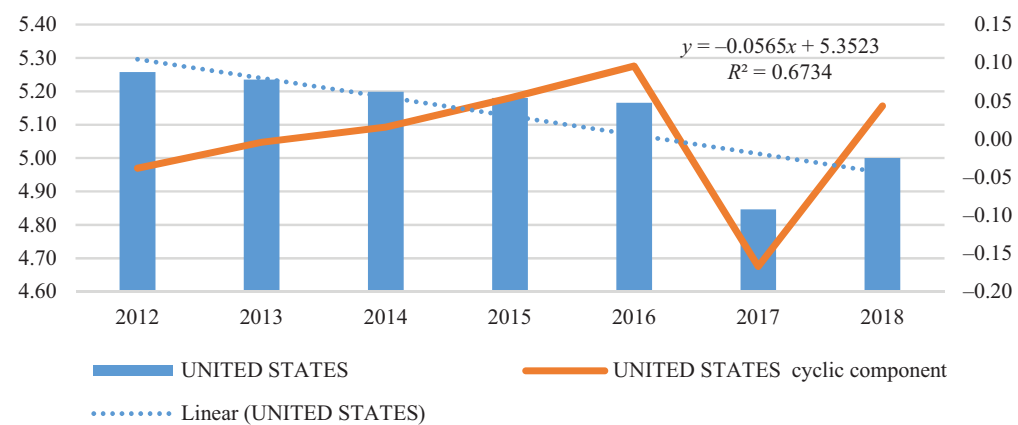

Figure A4. Visualization of the input time series of the BASEL AML INDEX, trend and cyclic components in the context of the United States for the period from 2012 to 2018 (source: authors' calculation) 


\section{APPENDIX B}

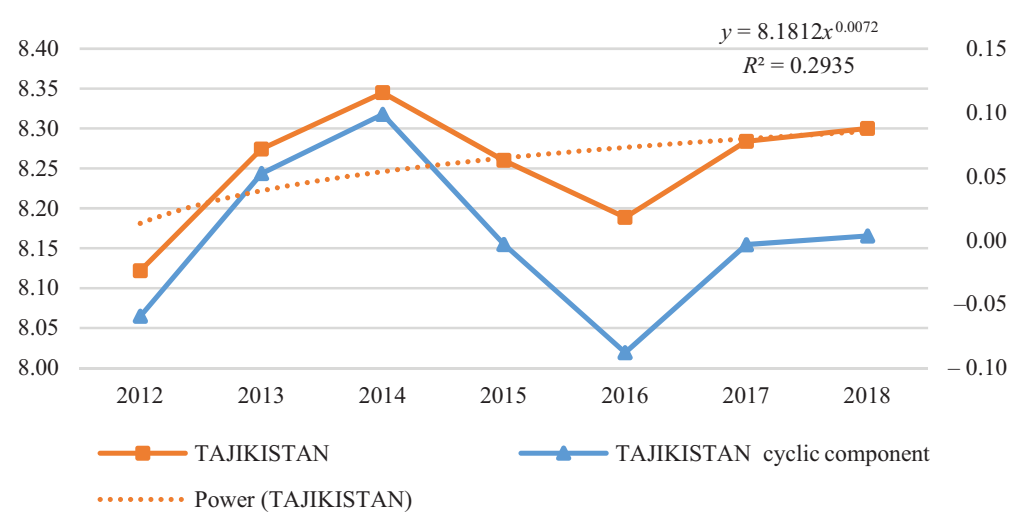

Figure B1. Visualization of the input time series of the BASEL AML INDEX, trend and cyclic components in the context of Tajikistan for the period from 2012 to 2018 (source: authors' calculation)

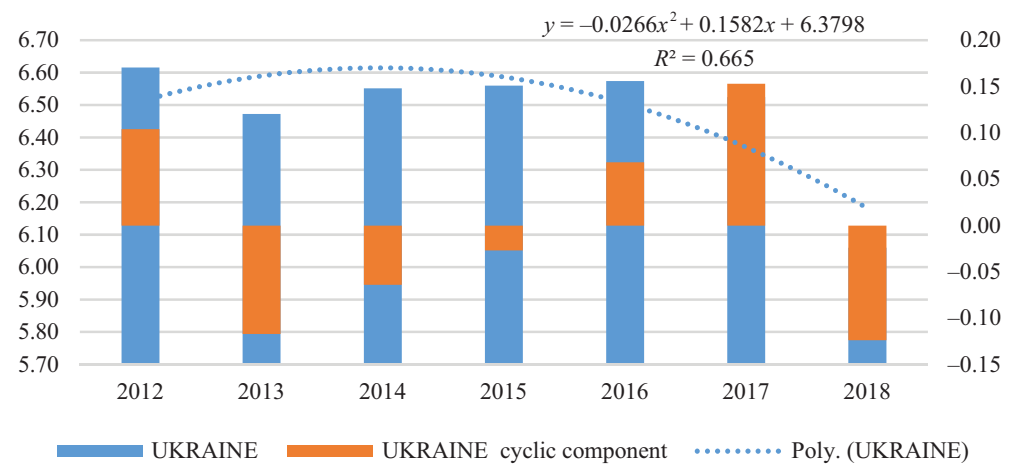

Figure B2. Visualization of the input time series of the BASEL AML INDEX, trend and cyclic components in the context of Ukraine for the period from 2012 to 2018 (source: authors' calculation)

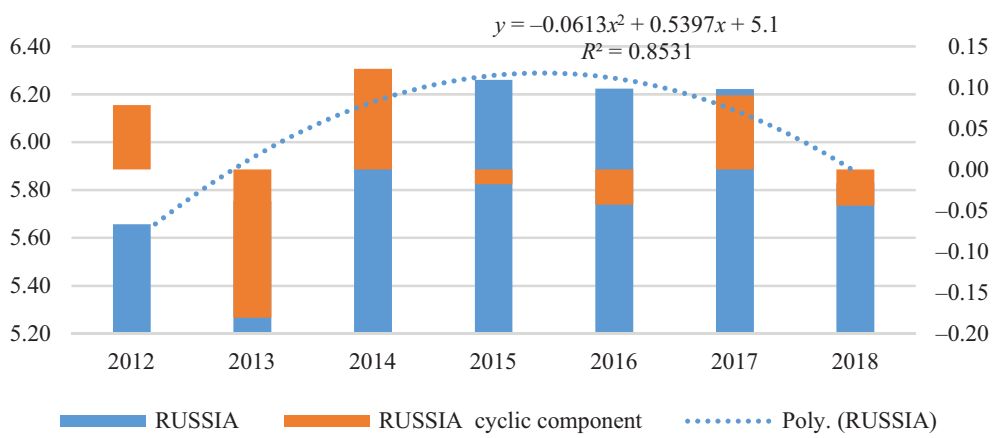

Figure B3. Visualization of the input time series of the BASEL AML INDEX, trend and cyclic components in the context of Russia for the period from 2012 to 2018 (source: authors' calculation)

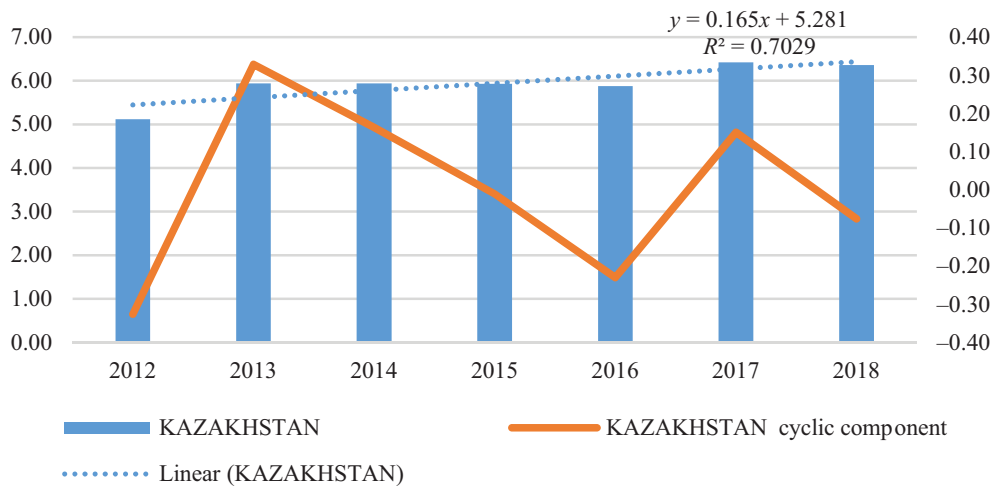

Figure B4. Visualization of the input time series of the BASEL AML INDEX, trend and cyclic components in the context of Kazakhstan for the period from 2012 to 2018 (source: authors' calculation) 

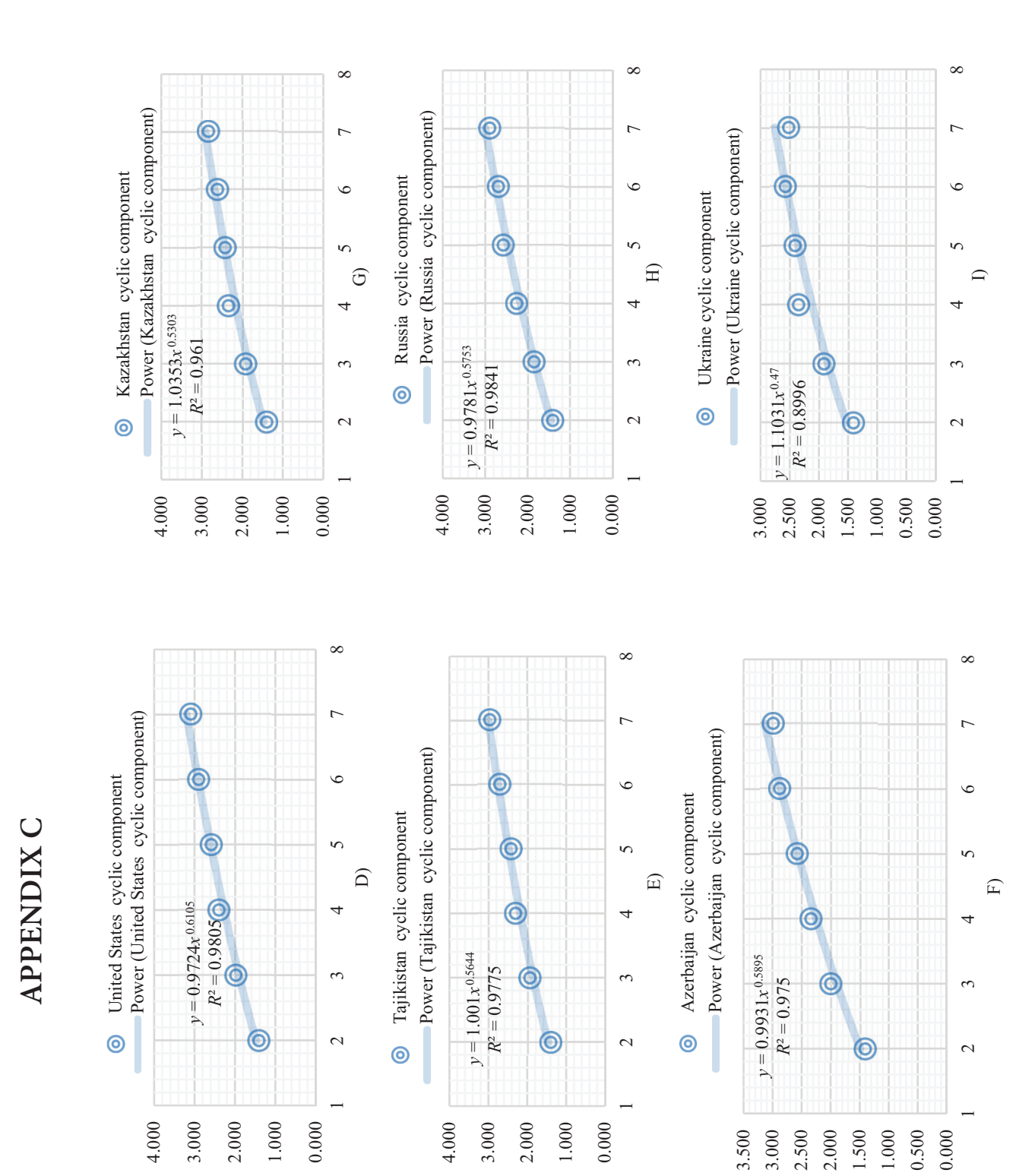

苛
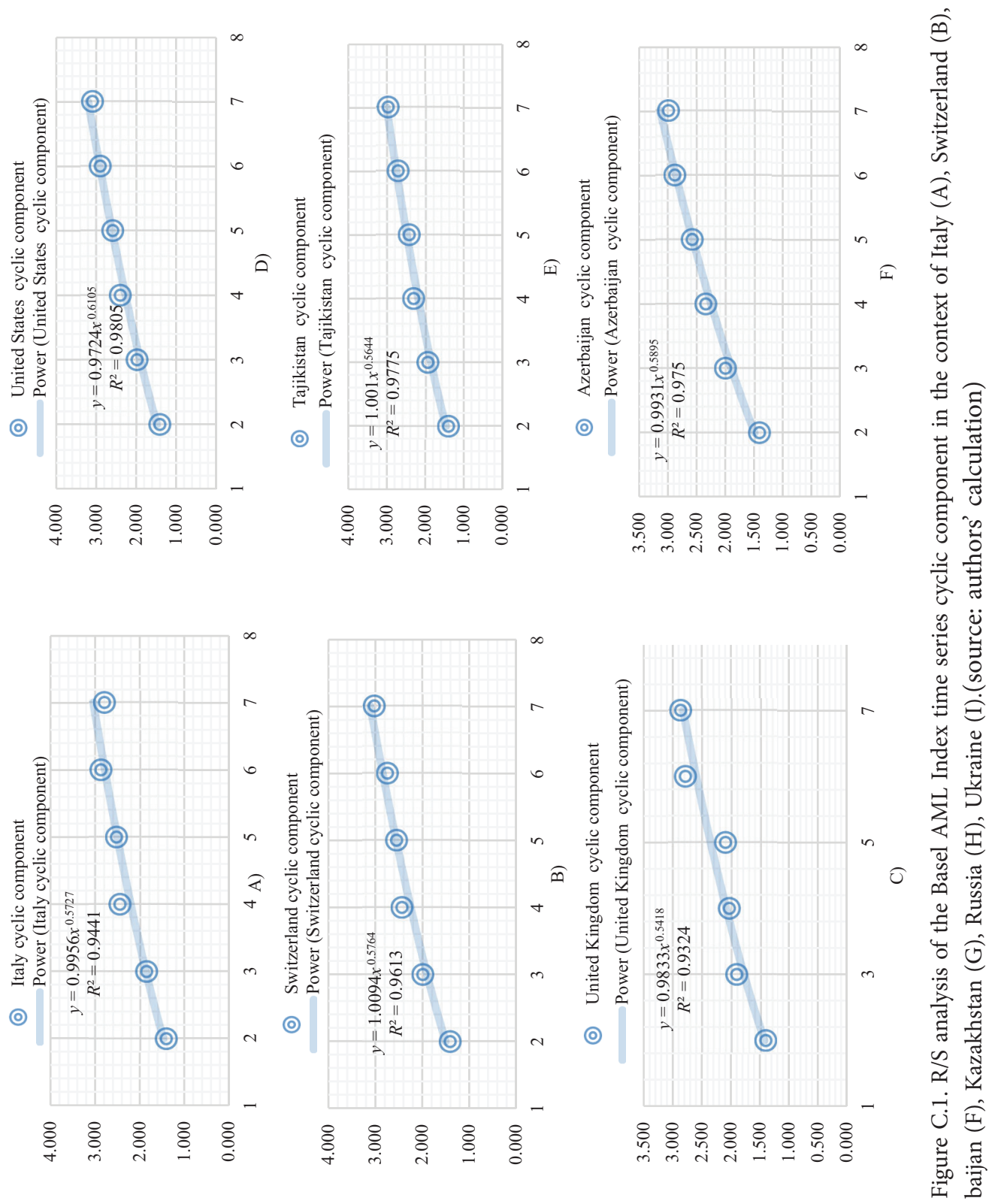